University of Nebraska - Lincoln

DigitalCommons@University of Nebraska - Lincoln

$7-5-2013$

\title{
Identification of Species of Botryosphaeriaceae Causing Bot Gummosis in Citrus in California
}

A.O. Adesemoye

J.S. Mayorquin

D.H. Wang

M. Twizeyimana

S.C. Lynch

See next page for additional authors

Follow this and additional works at: https://digitalcommons.unl.edu/plantpathpapers

Part of the Other Plant Sciences Commons, Plant Biology Commons, and the Plant Pathology Commons

This Article is brought to you for free and open access by the Plant Pathology Department at DigitalCommons@University of Nebraska - Lincoln. It has been accepted for inclusion in Papers in Plant Pathology by an authorized administrator of DigitalCommons@University of Nebraska - Lincoln. 


\section{Authors}

A.O. Adesemoye, J.S. Mayorquin, D.H. Wang, M. Twizeyimana, S.C. Lynch, and Akif Eskalen 


\title{
Identification of Species of Botryosphaeriaceae Causing Bot Gummosis in Citrus in California
}

A. O. Adesemoye, Department of Microbiology, Adekunle Ajasin University, P.M.B. 001, Akungba-Akoko, Ondo State, Nigeria; and J. S. Mayorquin, D. H. Wang, M. Twizeyimana, S. C. Lynch, and A. Eskalen, Department of Plant Pathology and Microbiology, University of California, Riverside 92521

\begin{abstract}
Adesemoye, A. O., Mayorquin, J. S., Wang, D. H., Twizeyimana, M., Lynch, S. C., and Eskalen, A. 2014. Identification of species of Botryosphaeriaceae causing bot gummosis in citrus in California. Plant Dis. 98:55-61.

Members of the Botryosphaeriaceae family are known to cause Bot gummosis on many woody plants worldwide. To identify pathogens associated with Bot gummosis on citrus in California, scion and rootstock samples were collected in 2010 and 2011 from five citrusgrowing counties in California. Symptoms observed on citrus included branch cankers, dieback, and gumming. Various fungal species were recovered from necrotic tissues of branch canker and rootstock samples. Species were identified morphologically and by phylogenetic comparison as 'Eureka' lemon, 'Valencia', 'Washington Navel', 'Fukumoto', grapefruit, 'Satsuma', and 'Meyer' lemon. Species were identified morphologically and by phylogenetic comparison of the complete sequence of the internal transcribed spacer regions, $\beta$-tubulin gene, and elongation factor $\alpha-1$ genes with those of other species in GenBank. A consensus-unrooted most parsimonious tree resulting from multigene phylogenetic analysis showed the existence of three

major clades in the Botryosphaeriaceae family. In total, 74 isolates were identified belonging to the Botryosphaeriaceae family, with Neofusicoccum spp., Dothiorella spp., Diplodia spp., (teleomorph Botryosphaeria), Lasiodiplodia spp., and Neoscytalidium dimidiatum (teleomorphs unknown) accounting for 39, 25, 23, 10, and 3\% of the total, respectively. On inoculated Eureka lemon shoots, lesion length was significantly different $(P<0.05)$ among 14 isolates recovered from portions of cankered tissues of the original trees. Lesion lengths were significantly longer $(P<0.05)$ for shoots inoculated with isolates of Neofusicoccum luteum and shorter for shoots inoculated with isolates of Dothiorella viticola $(P<0.05)$ than those of other species. Identifying the distribution and occurrence of these fungal pathogens associated with Bot gummosis is useful for management applications during occasional outbreaks in California.
\end{abstract}

During the 2012-13 growing season, the U.S. citrus industry produced 11.2 million tons of citrus, worth approximately $\$ 3.15$ billion. Florida accounted for $63 \%$ of U.S. production and California produced $34 \%$ of the total amount (43). The California citrus industry comprises numerous varieties, including grapefruit, lemon, lime, orange, tangerine, and many hybrids. Given that the citrus industry is one of California's largest agricultural industries (21), the health of these commodities is critically important.

Growers and county farm advisors have observed branch canker and dieback on various citrus cultivars throughout citrus-growing regions of California for over a decade (G. Bender [San Diego County Farm Advisor] and N. O'Connell [Tulare County Farm Advisor], personal communication). Initial symptoms are scattered dieback of twigs and branches, where portions have dead outer bark over a sunken canker. The dead bark may exude gum; the cambial layer of wood underneath the bark may turn brown to yellowish. In an initial survey, Neofusicoccum australe and $N$. parvum (Botryosphaeriaceae family) were recovered from these cankered tissues (2). Isolates were tentatively identified to species shortly after recovery by 98 to $100 \%$ homology with available sequences in GenBank. However, several previously unrecorded species associated with citrus in the Botryosphaeriaceae family were recovered from symptomatic tissues of cankered branch samples submitted by local growers and farm advisors for disease identification. This prompted the need for a more detailed survey and study.

Species in the Botryosphaeriaceae family were reported on citrus as early as the1900s $(16,30)$. Since that time, identification and

Corresponding author: A. Eskalen, E-mail: akif.eskalen@ucr.edu

Accepted for publication 5 July 2013.

http://dx.doi.org/10.1094/PDIS-05-13-0492-RE

(C) 2014 The American Phytopathological Society taxonomy of this family has long been complex because the teleomorph is rarely seen in nature. Consequently, anamorphic characteristics have been used for identification. The combination of molecular methods and anamorphic characters has simplified species identification in the Botryosphaeriaceae family (12) but has not recently been done for those associated with citrus.

The impact of species in the Botryosphaeriaceae family on citrus has not been extensively explored. Furthermore, many of these previously unrecorded species on citrus that were recovered from submitted extension samples were the same as those found causing dieback on other crops, which include avocado, grapevine, olive, almond, walnut, and pistachio $(19,24,25,41,49,51,54)$. Thus, it is highly likely that the diversity of fungi in the Botryosphaeriaceae family on citrus is not well understood and, moreover, is causing more damage than previously thought.

The objectives of this study were to (i) determine the occurrence of species in the Botryosphaeriaceae family associated with branch canker and dieback on citrus throughout the major citrus-growing regions of California; (ii) identify these species based on morphological characteristics, sequence data, and phylogenetic analysis; and (iii) determine their pathogenicity on citrus.

\section{Materials and Methods}

Fungal collections and isolations. Five citrus-growing counties in California-including Riverside, San Diego, San Luis Obispo, Tulare, and Ventura-were visited in 2010 and 2011 (Table 1). Approximately 15 to 20 pieces of trunk and branch with canker symptoms were collected from 10 randomly selected trees (approximately 5 to 60 years old) in each of 5 to 10 orchards per county, depending on orchard density. Samples were transported in a cooler to the laboratory at the University of California, Riverside. Trunk and branch pieces were rinsed with deionized water to remove organic debris, dried with paper towels, then briefly flamed after dipping in 95\% ethanol for $3 \mathrm{~s}$. Small sections (approximately 2 to $3 \mathrm{~mm}^{2}$ ) at the margin of necrotic wood tissue of cankered 
branches were cut with a sterile scalpel and five to six pieces were placed onto potato dextrose agar (PDA; Difco Laboratories) amended with $0.01 \%$ tetracycline (Sigma-Aldrich) (PDA-tet). Cultures were incubated in the dark for 4 days at $25^{\circ} \mathrm{C}$. Pure cultures of fungal isolates were obtained by transferring hyphal tips from colony margins onto fresh PDA-tet plates.

Molecular characterization and phylogenetic analyses. Genomic DNA from fungal isolates was extracted using the following modifications of the methods described by Cenis (10). Approximately $50 \mu \mathrm{g}$ of mycelium was scraped from the surface of a pure culture grown on PDA-tet and added to a 2.0-ml screw-cap tube with $500 \mu \mathrm{l}$ of extraction buffer and approximately $300 \mathrm{mg}$ of $1.0-$ mm-diameter glass beads (BioSpec Products). Tubes were then placed into an MP Bio Fast Prep-24 instrument (MP Biomedicals Inc.) at $4 \mathrm{M} / \mathrm{s}$ for $30 \mathrm{~s}$. Polymerase chain reaction (PCR) was conducted in a thermal cycler (Bio-Rad Laboratories, Inc.) using three different markers: $\mathrm{Bt} 2 \mathrm{a}$ and $\mathrm{Bt} 2 \mathrm{~b}$ for the $\beta$-tubulin gene; internal transcribed spacer (ITS) 4 and ITS5 for the ITS1, ITS2, and 5.8S regions of ribosomal DNA (52); and EF1-728F and EF1-986R for translation elongation factor $(\mathrm{EF}) \alpha-1(48,52)$. Each PCR reaction contained $12.5 \mu \mathrm{l}$ of GoTaq Green Master Mix (Promega Corp.), $9.3 \mu \mathrm{l}$ of PCR-grade water, $0.6 \mu \mathrm{l}$ of $10 \mu \mathrm{M}$ each primer, and $2 \mu \mathrm{l}$ of DNA template. The reaction protocol for ITS and $\beta$-tubulin included an initial preheat at $94^{\circ} \mathrm{C}$ for $2 \mathrm{~min}$; followed by 35 cycles of denaturation at $94^{\circ} \mathrm{C}$ for $15 \mathrm{~s}$, annealing at $58^{\circ} \mathrm{C}$ for $15 \mathrm{~s}$, and extension at $72^{\circ} \mathrm{C}$ for $45 \mathrm{~s}$; and final extension at $72^{\circ} \mathrm{C}$ for $5 \mathrm{~min}$ (35). The translation EF $\alpha-1$ included an initial denaturation at $95^{\circ} \mathrm{C}$ for $8 \mathrm{~min}$; followed by 35 cycles of 95,58 , and $72^{\circ} \mathrm{C}$ for 15,20 , and $60 \mathrm{~s}$, respectively; and a final extension at $72^{\circ} \mathrm{C}$ for $5 \mathrm{~min}(7)$.

The PCR products were separated by gel electrophoresis in $1.5 \%$ agarose gels in $1 \times$ Tris-boric acid-EDTA (TBE) buffer and were photographed with Dark Reader DR88X transilluminator (Clare Chemical Research). The PCR products were purified using Isopure PCR purification kit (Denville Scientific Inc.). The quality of the PCR products was estimated using NanoDrop Spectrophotometer ND-1000 (Thermal Scientific). Sequencing was done at the
Institute for Integrative Genome Biology, University of California, Riverside. Sequences were edited using Sequencher software 4.6 (Gene Codes, Corp.) and locally aligned using ClustalX 2.1-Mac OSX (Conway Institute, UCD) (38). Sequences were used to search for similar sequences using the BLAST program (version 2.0; National Center for Biotechnology Information, United States National Institutes of Health).

Sequences of representative isolates of the Botryosphaeriaceae family from citrus cankers in the present study (Table 1) and sequences from other studies in GenBank (Table 2) were used in a phylogenetic analysis performed using MEGA 5.0. The Guignardia philoprina (CBS447.68) sequence from GenBank was chosen as an outgroup. Maximum parsimony analysis was performed using the heuristic search with a close-neighbor interchange branch-swapping option. Alignment gaps were treated as missing data. Support for each branch in the inferred trees was evaluated by 1,000 bootstrap replications. Prior to the heuristic search of the most-parsimonious tree, a partition homogeneity test performed in PAUP* (version 4.0b10; Sinauer Associates) using 1,000 random repartitions was conducted to determine whether the ITS, $\beta$-tubulin, and EF sequence data could be combined. Tree length, consistency index (CI), retention index (RI), rescaled consistency index (RC), and homoplasy index (HI) were calculated using MEGA5.0.

Morphological identification. Isolates were grown on PDA-tet for the initial identification (11,24). Fungal isolates were transferred to oatmeal agar medium for conidial development and further morphological characterization. Oatmeal agar was prepared by autoclaving $30 \mathrm{~g}$ of oat and $15 \mathrm{~g}$ of agar in 1 liter of distilled water. Plates were incubated at $25^{\circ} \mathrm{C}$ under a 12-h daily photoperiod for 2 to 4 weeks to allow pycnidium formation. The length and width of 50 conidia/isolate were measured using a compound microscope (Olympus BX40 with a Leica DFC420 camera) and the SPOT Imaging Software (Diagnostic Instruments. The conidial characteristics observed were compared with those that were reported in previous studies $(6,11,24,27,35,36,53)$.

Table 1. Representative isolates of species in the Botryosphaeriaceae recovered from citrus samples with branch canker in this study

\begin{tabular}{|c|c|c|c|c|c|c|c|}
\hline \multirow[b]{2}{*}{ Species } & \multirow[b]{2}{*}{ Isolate $^{\text {b }}$} & \multirow[b]{2}{*}{ County $^{c}$} & \multirow[b]{2}{*}{ Host } & \multirow[b]{2}{*}{ Variety } & \multicolumn{3}{|c|}{ GenBank number ${ }^{a}$} \\
\hline & & & & & ITS & $\beta$-tubulin & $\mathbf{E F}$ \\
\hline Diplodia mutila & UCP130* & Tulare & Citrus sinensis & Fukumoto & JF271751 & JF271769 & JF271787 \\
\hline D. mutila & UCR1665 & Ventura & C. limon & Lisbon lemon & JQ659283 & JQ659295 & JQ659271 \\
\hline D. mutila & UCR1670 & San Diego & C. sinensis & Valencia & JQ659284 & JQ659296 & JQ659272 \\
\hline Diplodia seriata & UCR 1653 & San Diego & C. sinensis & Valencia & JQ659282 & JQ659294 & JQ659270 \\
\hline D. seriata & UCR 1687 & Ventura & C. limon & Lisbon lemon & JQ659285 & JQ659297 & JQ659273 \\
\hline D. seriata & UCR 1795 & San Diego & C. latifolia & Bearss Lime & JQ659286 & JQ659298 & JQ659274 \\
\hline Dothiorella iberica & UCP124* & Tulare & C. sinensis & Fukumoto & JF271750 & JF271768 & JF271786 \\
\hline Dothiorella viticola & UCP61* & Tulare & C. sinensis & Valencia & JF271747 & JF271765 & JF271783 \\
\hline D. viticola & UCP105* & Tulare & C. sinensis & Parent Washington & JF271748 & JF271766 & JF271784 \\
\hline D. viticola & UCP134* & Tulare & C. sinensis & Parent Washington & JF271752 & JF271770 & JF271788 \\
\hline D. viticola & UCR1104 & San Diego & C. sinensis & Valencia & JF271757 & JF271775 & JF271792 \\
\hline D. viticola & UCR1796 & San Diego & C. latifolia & Bearss Lime & JQ659287 & JQ659299 & JQ659275 \\
\hline Lasiodiplodia parva & UCR 1056 & Tulare & Citrus sp. & Unknown & JQ659278 & JQ659290 & JQ659265 \\
\hline L. parva & UCR 1057 & Tulare & Citrus sp. & Unknown & JQ659279 & JQ659291 & JQ659266 \\
\hline Neofusicoccum australe & UCR1099* & San Diego & C. sinensis & Valencia & JF271756 & JF271774 & JF271791 \\
\hline N. australe & UCR $1110^{*}$ & Riverside & C. unshiu & Satsuma & JF271758 & JF271776 & JF271793 \\
\hline N. australe & UCR1111* & Riverside & C. unshiu & Satsuma & JF271759 & JF271777 & JF271794 \\
\hline N. luteum & UCR1097* & San Diego & C. sinensis & Valencia & JF271755 & JF271773 & JF271790 \\
\hline N. luteum & UCR1177* & SLO & C. limon & Lemon & JF271763 & JF271781 & JF271797 \\
\hline N. luteum & UCR1180* & SLO & C. limon & Lemon & JF271764 & JF271782 & JF271798 \\
\hline N. mediterraneum & UCP114* & Tulare & C. sinensis & Fukumoto & JF271749 & JF271767 & JF271785 \\
\hline N. parvum & UCR1166* & Ventura & C. limon & Meyer Lemon & JF271762 & JF271780 & JF271796 \\
\hline N. parvum & UCR1170 & Ventura & C. limon & Meyer Lemon & JQ659280 & JQ659292 & JQ659268 \\
\hline N. parvum & UCR1171 & Ventura & C. limon & Meyer Lemon & JQ659281 & JQ659293 & JQ659269 \\
\hline N. parvum & UCR1798 & Tulare & C. sinensis & Cara Cara & JQ659288 & JQ659300 & JQ659276 \\
\hline Neoscytalidium dimidiatum & UCR1087* & San Diego & C. paradisi & Red Blush Grapefruit & JF271754 & JF271772 & JF271789 \\
\hline
\end{tabular}


Pathogenicity test. Three isolates each of eight species in the Botryosphaeriaceae family that were recovered from citrus cankers were used in the pathogenicity test (Table 1). These randomly selected isolates were used to inoculate $30-\mathrm{cm}$-long detached healthy green shoots collected from 1- to 2-year-old 'Eureka' lemon trees. One wound per shoot was made using a 3-mm cork borer. A 3mm-diameter mycelial plug from 3- to 5-day-old culture growing on PDA-tet was placed on the freshly wounded surface of each shoot, and the inoculated area was covered with Parafilm (2). Inoculated shoots and controls (mock-inoculated with agar plugs) were covered with petroleum jelly at their ends to prevent desiccation and incubated at $25^{\circ} \mathrm{C}$ in moist chambers for 4 weeks. After incubation, lesion length was recorded on each shoot. The experiment was arranged in a completely randomized design with five replications and was conducted twice. Small pieces of necrotic tissue from the edges of each lesion were placed on PDA-tet in plates and incubated at room temperature. Fungal colonies were confirmed morphologically and using molecular identification techniques.

Data analysis. Lesion length data from both runs were tested for homogeneity of error variance by analysis of variance (ANOVA) in SAS (version 9.2; SAS Institute Inc.). Because no heterogeneity was detected, data were pooled for the final ANOVA analysis. Means lesion lengths among isolates were compared using a Tukey's honestly significant difference mean separation test at $\alpha=$ 0.05 .

\section{Results}

Fungal collections and isolations. Cankers were found on the main trunk, branches, twigs, and exposed roots (roots above ground; Fig. 1), with sampled trees ranging in age from approximately 5 to 60 years old. On heavily infected trees, especially young trees, death of branches or death of the entire plant was observed. Botryosphaeriaceae isolates were recovered from rootstock samples, including 'Carrizo' citrange (Citrus sinensis (L.)
Osb. $\times$ Poncirus trifoliata L.), 'Macrophylla' (C. macrophylla Wester), 'Sour orange' (C. aurantium L.), and 'Volkameriana' $(C$. volkameriana L.); and scions 'Bearss' lime (C. latifolia Tan.), 'Cara Cara Pink' orange (C. sinensis (L.) Osb.), Eureka lemon $(C$. limon Burm.f.), 'Fukumoto' orange (C. sinensis), grapefruit $(C$. paradisi Macf.), lemon (C. limon), 'Lisbon' lemon (C. limon), 'Meyer' lemon (C. meyeri), 'Parent Washington' orange $(C$. sinensis), 'Red Blush' grapefruit ( $C$. paradisi Macf.), 'Satsuma' orange (C. unshiu Marc.), and 'Valencia' orange (C. sinensis).

Based on phylogenetic analyses, colony morphology, and conidial characteristics (see below), 74 isolates belonging to the Botryosphaeriaceae family were identified (Fig. 2). Of the total Botryosphaeriaceae isolates recovered from samples, $37 \%$ were recovered from Tulare County and $28 \%$ were recovered from San Diego County. Ventura, Riverside, and San Luis Obispo Counties had 18,12 , and $5 \%$ of the total, respectively. Neofusicoccum spp. accounted for $39 \%$ of all isolates, and the remaining isolates were identified as Dothiorella spp. (25\%), Diplodia spp. (23\%), Lasiodiplodia spp. (10\%), and Neoscytalidium dimidiatum (3\%). Among Neofusicoccum spp., Neofusicoccum parvum was the most frequently recovered (36\%), followed by $N$. australe and $N$. luteum that each accounted for $27 \%$ of the Neofusicoccum spp. recovered. $N$. mediterraneum had the lowest number (10\%). Other fungal genera sporadically isolated from citrus cankers were Alternaria, Phomopsis, and Cladosporium.

Phylogenetic analysis. The nonsignificant partition-homogeneity test $(P=0.180)$ indicated congruence between ITS, $\beta$-tubulin, and EF $\alpha-1$ sequence sets and, thus, the three sets were combined for further phylogenetic analysis. Of the 1,219 nucleotides analyzed, 394 were parsimony informative. Maximum parsimony analysis yielded 300 trees (length $=1045, \mathrm{CI}=0.74, \mathrm{RI}=0.93, \mathrm{RC}$ $=0.69, \mathrm{HI}=0.26$ ).

A consensus-unrooted most-parsimonious tree showed the existence of three major clades in the Botryosphaeriaceae isolates. The

Table 2. Sequences and their description of the Botryosphaeriaceae species obtained from GenBank used in the phylogenetic study

\begin{tabular}{|c|c|c|c|c|c|c|}
\hline \multirow[b]{2}{*}{ Isolate $^{b}$} & \multirow[b]{2}{*}{ Species } & \multirow[b]{2}{*}{ Host } & \multirow[b]{2}{*}{ Origin } & \multicolumn{3}{|c|}{ GenBank number ${ }^{a}$} \\
\hline & & & & ITS & $\beta$-Tubulin & EF \\
\hline PD75 & Diplodia mutila & Ilex $\mathrm{sp}$. & United States & GU251119 & GU251779 & GU251251 \\
\hline CBS112553 & D. mutila & Vitis vinifera & Portugal & AY259093 & DQ458850 & AY573219 \\
\hline UCD288Ma & D. mutila & $V$. vinifera & California & DQ008313 & DQ008336 & EU012411 \\
\hline SDZ-01 & Diplodia seriata & Vitis sp. & China & HQ629954 & HQ629956 & HQ629958 \\
\hline SDZ-02 & D. seriata & Vitis sp. & China & HQ629955 & HQ629957 & HQ629959 \\
\hline GA-422 & D. seriata & Prunus persica & China & HQ660463 & HQ660477 & HQ660489 \\
\hline CBS119049 & D. seriata & Vitis sp. & Italy & DQ458889 & DQ458857 & DQ458874 \\
\hline CBS113188 & Dothiorella iberica & Quercus suber & Spain & AY573198 & EU673097 & EU673278 \\
\hline CBS115041 & D. iberica & Q. ilex & Spain & AY573202 & EU673096 & AY573222 \\
\hline CBS117006 & Dothiorella viticola & $\bar{V}$. vinifera & Spain & AY905555 & EU673103 & AY905562 \\
\hline UCD1435SLO & D. viticola & $V$. vinifera & California & EF202007 & EF202014 & EF202021 \\
\hline CBS117009 & D. viticola & $V$. vinifera & Spain & AY905554 & EU673104 & AY905559 \\
\hline CMW28309 & Lasiodiplodia parva & Terminalia ivorensis & Cameroon & GQ469962 & GQ469894 & GQ469904 \\
\hline CMW28333 & L. parva & T. superba & Cameroon & GQ469961 & GQ469892 & GQ469903 \\
\hline PD298 & Neofusicoccum australe & Vaccinium sp. & Chile & GU251220 & GU251880 & GU251352 \\
\hline UCD1314So & N. australe & Vitis vinifera & California & DQ008323 & DQ008346 & GU294732 \\
\hline CMW6837 & $N$. australe & Acacia sp. & Australia & AY339262 & AY339254 & AY339270 \\
\hline CBS110497 & N. luteum & $V$. vinifera & Portugal & EU673311 & EU673092 & EU673277 \\
\hline CMW10310 & N. luteum & Vitis sp. & Portugal & AY339259 & AY339251 & AY339267 \\
\hline UCD2057Te & N. luteum & $V$. vinifera & California & DQ233604 & DQ233625 & EU012414 \\
\hline CBS121558 & N. mediterraneum & $V$. vinifera & California & GU799463 & GU799461 & GU799462 \\
\hline UCCE825A & N. mediterraneum & Juglans regia & California & HM443604 & HM443606 & HM443608 \\
\hline UCD720SJ & N. mediterraneum & V. vinifera & California & GU799452 & GU799475 & GU799483 \\
\hline UCD642So & N. parvum & $V$. vinifera & California & DQ008328 & DQ008351 & GU294741 \\
\hline PD17 & N. parvum & Prunus dulcis & United States & GU251143 & GU251803 & GU251275 \\
\hline PD59 & N. parvum & Prunus dulcis & United States & GU251146 & GU251806 & GU251278 \\
\hline PD105 & Neoscytalidium dimidiatum & Ficus sp. & United States & GU251108 & GU251768 & GU251240 \\
\hline PD103 & N. dimidiatum & Ficus sp. & United States & GU251106 & GU251766 & GU251238 \\
\hline PD104 & N. dimidiatum & Ficus $\mathrm{sp}$. & United States & GU251107 & GU251767 & GU251239 \\
\hline CBS447.68 & Guignardia philoprina & Taxus baccata & The Netherlands & FJ824768 & FJ824779 & FJ824773 \\
\hline
\end{tabular}

${ }^{a}$ Sequences of three gene loci (internal transcribed spacer [ITS]1-5.8S-ITS2 regions, $\beta$-tubulin gene, and elongation factor [EF] $\alpha-1$ ) were used.

${ }^{\mathrm{b}} \mathrm{CBS}=$ Centraalbureau Schimmelcultures, Utrecht, The Netherlands; CMW = Culture Collection Forestry and Agricultural Biotechnology Institute, University of Pretoria, South Africa; UCD = University of California, Davis. CBS447.68 (Guignardia philoprina) was added as an outgroup. 
first major clade (93\% bootstrap support) consisted of Neofusicoccum spp., and could be further resolved into four terminal subclades corresponding to isolates of $N$. luteum, $N$. australe, $N$. mediterraneum, and $N$. parvum isolates. The second major clade was
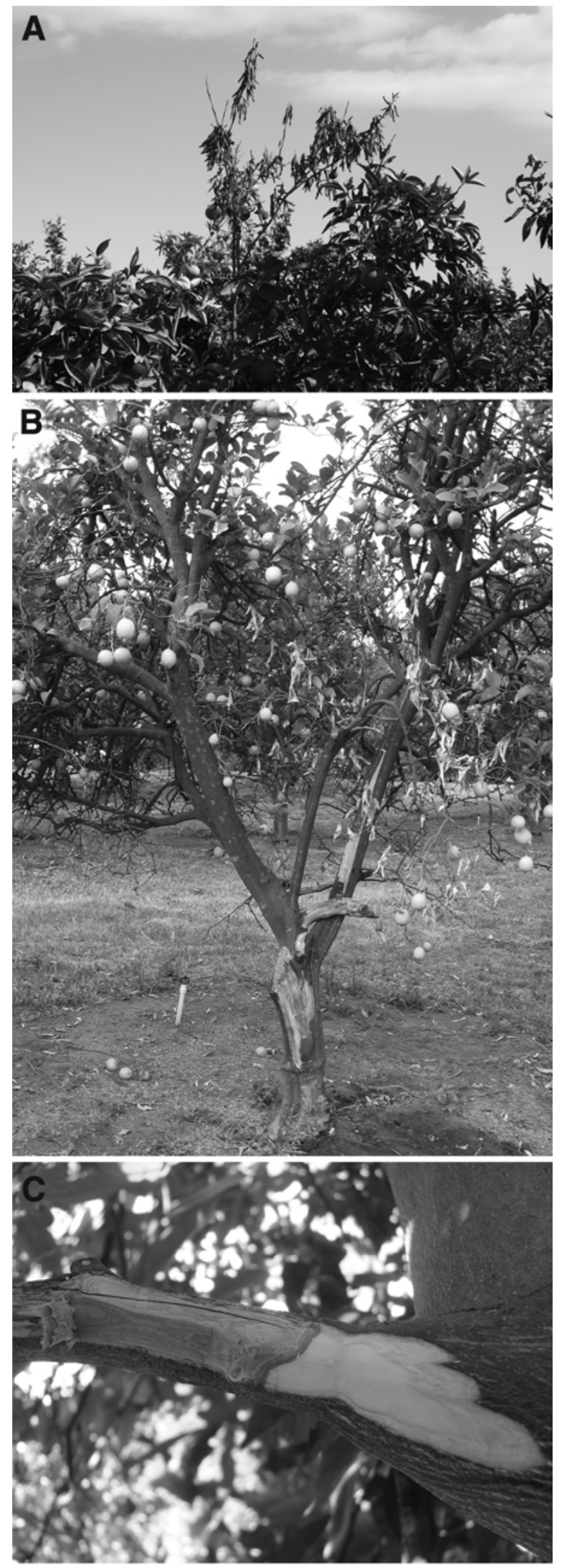

Fig. 1. Symptoms of Bot gummosis of citrus, including $\mathbf{A}$, branch dieback on 'Satsuma' mandarin; B, trunk and branch cankers on 'Eureka' lemon; and C, a cankered branch on 'Valencia' orange. divided into two subclades, the first (100\% bootstrap support) consisting of Neoscytalidium dimidiatum isolates, with the second subclade (100\% bootstrap support) consisting of isolates of Diplodia spp. and Lasiodiplodia pava. The Diplodia subclade had two subdivisions: Diplodia mutila and D. seriata. The third major clade had two subclades corresponding to Dothiorella iberica (100\% bootstrap support) and D. viticola (100\% bootstrap support) (Fig. 3).

Morphological identification. Two distinct groups were morphologically distinguished among Neofusicoccum spp. isolates. The first group consisted of isolates with conidia that were hyaline, aseptate, and fusiform. Cultural growth was characterized by either very pale yellow to bright yellow pigment in the center on the reverse side of the plate. These characteristics and conidial measurements (Table 3) matched those earlier described for Neofusicoccum australe and N. luteum $(24,35)$. Isolates in the second group had conidia that were hyaline, broadly ellipsoid to fusoid, and aseptate. This matched descriptions for $N$. mediterraneum and $N$. parvum (Table 3) $(24,36)$. Conidia of $N$. mediterraneum were larger than those of $N$. parvum (Table 3) (11).

Species of Dothiorella were characterized by conidia that were dark colored and septate early in their development, while still attached to conidiogenous cells (28). There were two species: $D$. iberica, which had conidia that had an internally verruculose wall and one septum; and D. viticola, which had conidia that were brown, oblong to subcylindrical, one-septum and occasionally slightly constricted at the septum, moderately thick-walled, externally smooth, and had rounded ends with a truncate base (48).

Diplodia spp. had thick-walled spores which, after release from pycnidia, became dark colored and septate. Two species could be distinguished among this group of isolates: Diplodia mutila which had conidia that were dark brown to black, thick-walled, oblong or cylindrical with rounded ends, and had conidiogenous cells that were holoblastic and cylindrical; and D. seriata (teleomorph: Botryosphaeria obtusa) $(29,48)$, which had conidia that were aseptate, thick-walled, and hyaline with a smooth outer surface and rough inner surface but became brown before they were released from the pycnidia and conidiogenous cells.

Lasiodiplodia spp. had conidia that were similar to those of Diplodia spp., except there were no striations in the conidial wall of Diplodia spp. One species, L. parva, was identified. It had conidia that were initially hyaline, aseptate, and ellipsoid to ovoid, with granular content and broadly rounded ends, and became pigmented, verruculose, and ovoid (1).

Neoscytalidium dimidiatum isolates had conidia that were ellipsoid to ovoid and hyaline, with an acutely rounded apex and truncate base, and were initially aseptate. Conidiogenous cells were hyaline, intermingled with paraphyses. The mycelium was composed of branched, septate, brown hyphae, which disarticulated into 0- to 1-septate phragmospores. The conidial measurements obtained for these Botryosphaeriaceae spp. in California on citrus are shown in Table 3, along with previously reported measurements $(6,11,24,27,35,36)$.

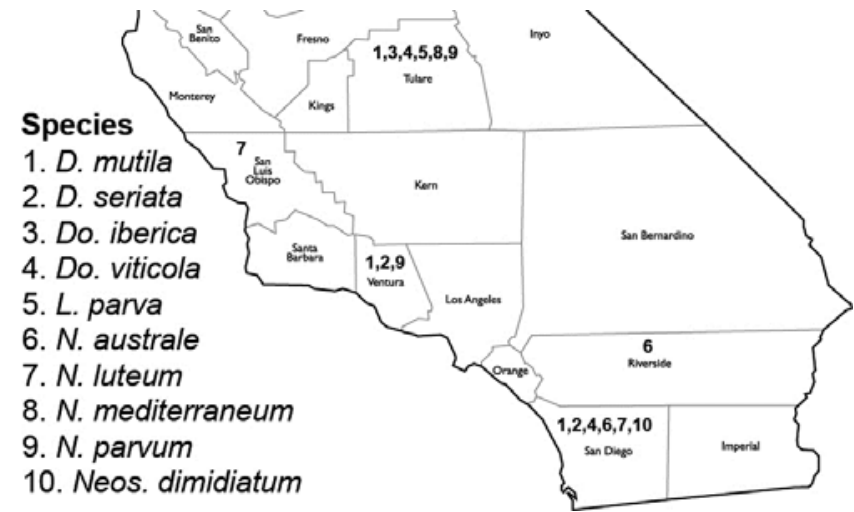

Fig. 2. California counties in which various species of Botryosphaeriaceae were detected in this study. 


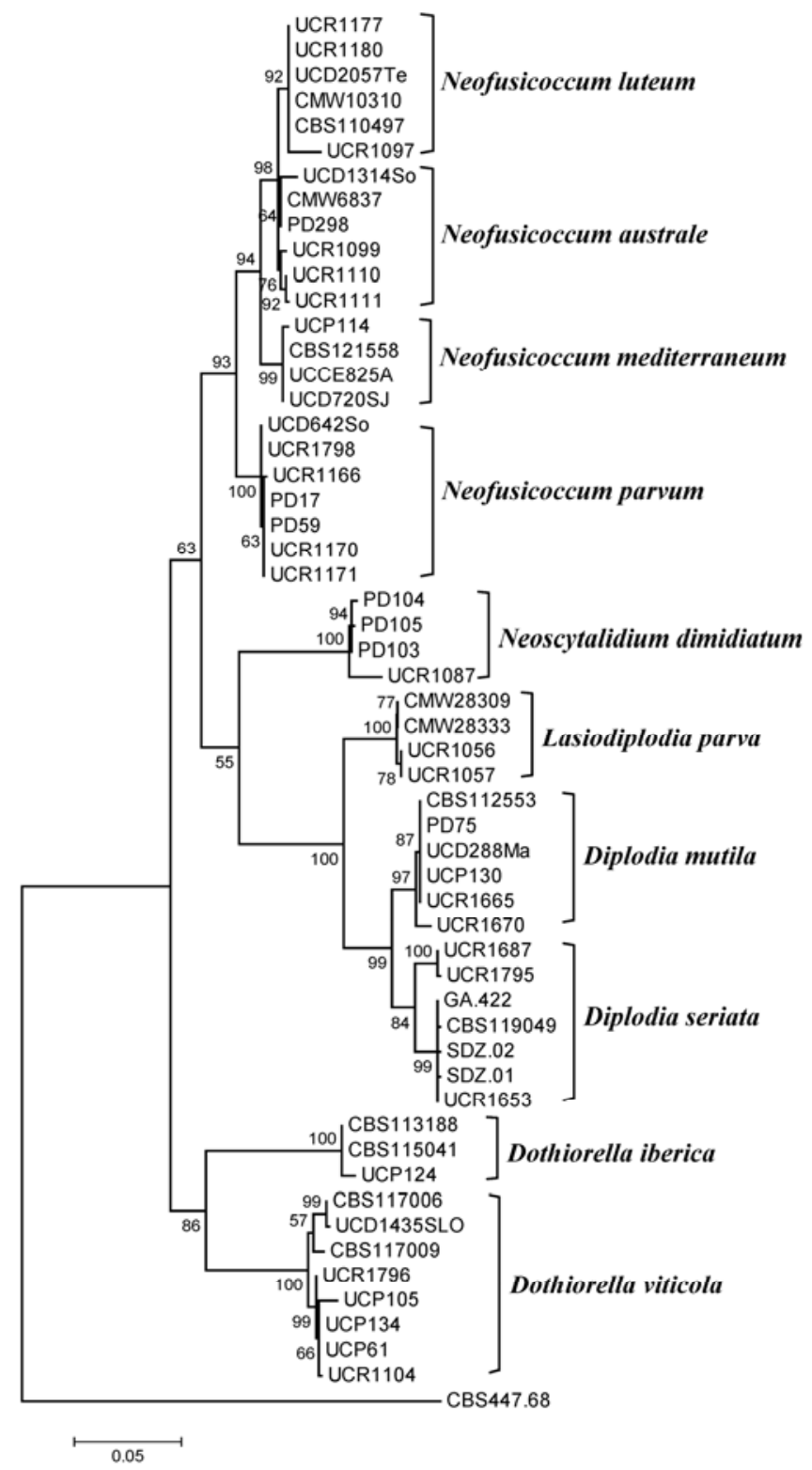

Fig. 3. Most parsimonious unrooted tree based on internal transcribed spacer (ITS)1, 5.8S ribosomal DNA, ITS2, partial $\beta$-tubulin gene, and elongation factor $\alpha-1$ sequences of isolates of species in the Botryosphaeriaceae family inferred from maximum parsimony analysis using MEGA 5 . Numbers on branches are bootstrap values $>50 \%$ in 1,000 replicates. Isolate CBS447.68 (Guignardia philoprina) was added as an outgroup. $\mathrm{CBS}=$ Centraalbureau Schimmelcultures, Utrecht, The Netherlands; $\mathrm{CMW}=$ Culture Collection Forestry and Agricultural Biotechnology Institute, University of Pretoria, South Africa; UCD = University of California, Davis; UCP = University of California, Riverside Citrus Project; UCR = University of California, Riverside.
Pathogenicity test. The 14 isolates significantly differed $(P<$ 0.05 ) in the size of lesions produced on Eureka lemon shoots (Fig. 4). Isolates of Neofusicoccum luteum had mean lesion lengths (10 $\mathrm{cm}$ each) that were significantly $(P<0.05)$ longer than those of other species. They were followed by mean lesion lengths of $N$. australe and $N$. parvum isolates (lesion lengths of 8.2 to $8.8 \mathrm{~cm}$ ). Dothiorella viticola had significantly $(P<0.05)$ shorter mean lesion lengths compared with those of other species (Fig. 3). In reisolations, all fungal pathogens used in inoculation were successfully recovered ( 80 to $100 \%$ ) when small pieces of inoculated shoots were placed on agar medium.

\section{Discussion}

In California, the importance and diversity of species in the Botryosphaeriaceae family in association with branch cankers on multiple hosts, including grapevine $(49,44,50)$, olive (51), avocado $(24,25,41,54)$, pistachio, (26) almond (19), and walnut (39), is increasingly becoming better understood (42). This study shows that citrus is now among the crops that are affected by species in the Botryosphaeriaceae family in California.

The taxonomy of the Botryosphaeriaceae family has significantly changed since species in this family were first discovered on citrus. Initially, Diplodia natalensis Pole-Evans was reported to be the cause of citrus dieback, gummosis, and fruit rot $(5,9,17)$. It was considered widespread in the Mediterranean basin (20), and reported in all citrus-growing areas of North and South America, all Mediterranean citrus-growing countries, South Africa (23), Japan, China, India, Australia, Indonesia, the Philippines (15,31), and the islands of the West Indies (16). However, further taxonomic revisions reported $D$. natalensis to be a synonym of Botryosphaeria rhodina (Berk. \& M.A. Curtis) Arx (anamorph L. theobromae (Pat.) Griffon \& Maubl.) (3). Later, the disease was referred to as Dothiorella gummosis, because it was believed to be caused by Dothiorella gregaria Sacc. (teleomorph B. ribis) (37). New information has revealed that the genus name Dothiorella has been misapplied to anamorphs with hyaline, aseptate conidia of the type normally associated with Fusicoccum and Neofusicoccum spp. (12). Moreover, further phylogenetic studies have shown that $B$. ribis is synonymous with $B$. parva (anamorph $N$. parvum) (35). Given this new information, the disease can no longer be referred to as 'Dothiorella gummosis'. Thus, we refer to this disease caused by species in the Botryosphaeriaceae family as 'Bot gummosis' of citrus.

In other citrus-growing countries, the fungus ' $\mathrm{B}$. ribis' was reported as the most common cause of gummosis on lemon in the Mediterranean basin (31), and caused disease in artificial inoculations of lemon, sour orange, and tangerine and sweet orange in Sicily (33). Along with Diplodia auranti, it was recovered among other fungi in association with cankers on lemon, orange, and sour orange on citrus in Sicily (18). Former authors believe them to be wound parasites (18), occurring on plants weakened by various diseases, and causing limited damage (14). Given our current understanding of the diversity of species in the Botryosphaeriaceae family in this study, and that they were aggressive on excised Eu-

Table 3. Conidial size of Botryosphaeriaceae isolates from citrus branch canker used in this study and comparison with previous studies

\begin{tabular}{|c|c|c|c|}
\hline \multirow[b]{2}{*}{ Species } & \multicolumn{2}{|c|}{ Conidial size $(\mu \mathrm{m})$ of Botryosphaeriaceae isolates ${ }^{\mathrm{a}}$} & \multirow[b]{2}{*}{ Reference } \\
\hline & In this study & In previous studies & \\
\hline Diplodia mutila & $28.9 \pm 2.1 \times 16.6 \pm 1.7$ & $23.1 \pm 2.7 \times 11.9 \pm 1.5$ & 29 \\
\hline D. seriata & $29.1 \pm 1.6 \times 11.8 \pm 0.6$ & $\ldots$ & $\ldots$ \\
\hline Dothiorella viticola & $28.1 \pm 1.3 \times 13.8 \pm 0.9$ & $\ldots$ & $\ldots$ \\
\hline D. iberica & $25.0 \pm 2.2 \times 8.5 \pm 1.3$ & $23.8 \pm 2.2 \times 13.9 \pm 1.5$ & 24 \\
\hline Lasiodiplodia parva & $26.0 \pm 3.4 \times 13.4 \pm 1.9$ & $22.6 \times 12.2$ & 6 \\
\hline Neofusicoccum australe & $17.3 \pm 3.6 \times 6.6 \pm 0.5$ & $18.9 \pm 1.2 \times 6.9 \pm 0.4$ & 24 \\
\hline N. luteum & $19.0 \pm 2.0 \times 6.3 \pm 0.8$ & $19.7 \times 5.6$ & 34,35 \\
\hline$N$. mediterraneum & $27.1 \pm 2.0 \times 6.8 \pm 0.9$ & $24 \times 6.0$ & 11 \\
\hline$N$. parvum & $16.4 \pm 2.6 \times 7.2 \pm 1.3$ & $17.2 \pm 1.6 \times 5.6 \pm 0.6$ & 29 \\
\hline Neoscytalidium dimidiatum & $7.6 \pm 1.2 \times 4.8 \pm 1.1$ & $12.8 \times 5.0$ & 36 \\
\hline
\end{tabular}

a Numbers are mean and standard deviation (in some cases) of length $\times$ width of 50 conidia from each species. 
reka Lemon shoots, it is likely that the diversity and impact of this family on citrus worldwide is greater than previously understood.

In this study, the presence and diversity of species in the Botryosphaeriaceae family associated with Bot gummosis of citrus in California is presented for the first time using phylogenetic analyses for identification. These species belong to five genera-including Diplodia, Dothiorella, Neofusicoccum, Neoscytalidium, and Lasiodiplodia - and are pathogenic when inoculated into excised Eureka lemon shoots. To our knowledge, this is the first report of L. parva causing branch canker disease on citrus and any crop in California. Of all species tested, $N$. luteum was the most aggressive to excised lemon shoots. Although disease progress on trunks and large branches of adult trees in the field could not be determined using excised lemon shoots in the present study, hostpathogen compatibility was demonstrated. Further studies will be required to determine disease impact on mature trees and conditions that may contribute to disease development. Pioneering works on this disease in the United States suggest that extremes of cold or heat, severe frost (15), and drought (31) are among various conditions (e.g. variety susceptibility, trees injured or weakened by insects, wind, and mineral nutrient deficiencies) that may contribute to the occurrence and development of the disease. Nevertheless, given that host compatibility was demonstrated for a diverse range of previously unrecorded species in the Botryosphaeriaceae family on citrus, that they were recovered from cankered tissues of citrus trees with symptoms of branch and tree death, and that these species have adversely impacted other hosts, these fungal species may be considered primary pathogens on citrus.

Because the taxonomic understanding, occurrence, and impact of Botryosphaeriacious species among multiple hosts is increasingly becoming better recognized, transmission of these pathogens among hosts that overlap in distribution needs to be explored. Úrbez-Torres et al. (51) showed that all but two fungal species that were identified on olive trees are important pathogens on grapevine and occur in olive orchards either near or adjacent to vineyards throughout the state (51). This appears to be the case in the current study for $N$. luteum on citrus, avocado, olive, and grapevine, which occur in geographically similar areas. Studies also suggest that species may vary by geographical region due to climatic conditions such as temperature $(22,44)$.

Although climate may play a role in fungal distribution, and proximity to suitable hosts may play a role in disease transmission and spread, several of the findings on citrus indicate that fungal distribution may be more complex. For example, optimal growth of

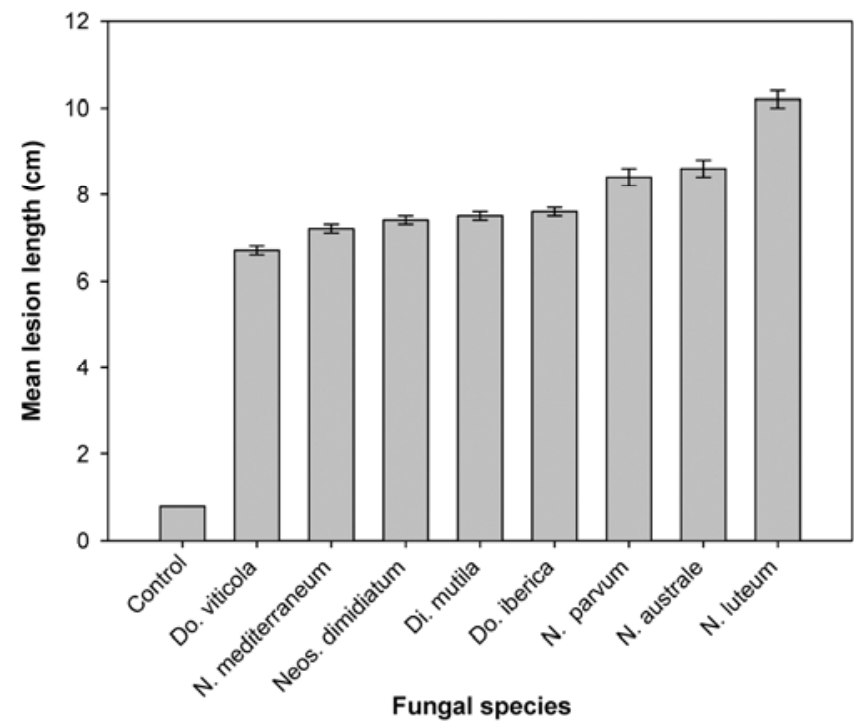

Fig. 4. Mean lesion lengths on excised 'Eureka' lemon shoots inoculated with isolates belonging to eight species of Botryosphaeriaceae. Vertical lines represent standard error of the mean according to Tukey's honestly significant difference mean separation test at $\alpha=0.05$.
L. theobromae occurs at 35 to $40^{\circ} \mathrm{C}$, and is more prevalent in grapevine vineyards and olive orchards throughout the warmer counties in California (Madera, Merced, Riverside, and Tulare; 22,49-51). However, this species was not recovered from citrus in the present study, where these crops grow. Another example is $D$. mutila, which was detected on citrus in the present study and grapevine in other studies $(46,49)$ in geographically separate regions throughout counties where they both occur. Dothiorella iberica occurs on both olive and citrus in Tulare County but has not been detected on citrus in Ventura County, where it infects avocado and olive (24,51). N. mediterraneum has a broader distribution on olive (51), almond, pistachio, and walnut (19) but, thus far, has only been detected on citrus in Tulare County. N. australe occurs on avocado and citrus in geographically overlapping areas but has not been detected on grapevine, where it has only been reported in northern California. In southern California, N. parvum has been found on citrus and avocado (24) but, thus far, has only been reported on grapevine in northern California (44). Neoscytalidium dimidiatum has been recovered from English walnut in Tulare County (8) and only citrus in San Diego County. Finally, Diplodia seriata, which has not yet been reported to occur south of the northern San Joaquin Valley, has only been recovered from citrus in southern California. Results from the survey in the present study shed light on where these various fungi are found on citrus in relation to other hosts and geography but more survey data will be needed to further substantiate these findings. Nonetheless, the complex distribution of these fungal species on a variety of hosts indicates the need to investigate mechanisms of transmission and infestation between hosts over a geographical range to determine effective strategies for management

Currently, the management of Bot gummosis on citrus may be achieved by pruning dead limbs and twigs and removing pruning waste from fields prior periods of rain. This strategy is based on results from studies on avocado and grapevine $(4,11,13,32,45,47)$; however, the efficacy of those cultural practices has not been evaluated. Pruning wounds, mechanical injury, frost, and sunburn damage have been reported to serve as points of entry for spores in the Botryosphaeriaceae family on other hosts $(11,13)$. In avocado and grapevine, spores are released from fruiting bodies present on branches or twigs and spread by rain splash and wind, typically between November and April $(13,50)$. Currently, there are no effective fungicides that can be used by growers to prevent cankers on citrus in California. However, the ability for fungicides to control occasional outbreaks of citrus cankers caused by species in the Botryosphaeriaceae family is currently being evaluated, based on studies on avocado (40).

\section{Acknowledgments}

We thank the California Citrus research board for funding this study; those involved with granting permission to conduct research on growers' lands, including pest control advisor J. Barcinas and farm advisors N. O'Connell (Tulare County), C. Kallsen (Kern County), B. Faber (Ventura County), G. Bender (San Diego County), and M. Bianchi (San Louis Obispo County); the growers for permission to survey their orchards; P. Rolshausen for previewing this manuscript; and the anonymous reviewers for their editorial comments.

\section{Literature Cited}

1. Abdollahzadeh, J., Javadi, A., Mohammadi, G. E., Zare, R., and Phillips, A. J. L. 2010. Phylogeny and morphology of four new species of Lasiodiplodia from Iran. Persoonia 25:1-10.

2. Adesemoye, A. O., and Eskalen, A. 2011. First report of Spencermartinsia viticola, Neofusicoccum australe, and $N$. parvum causing branch canker of citrus in California. Plant Dis. 95:770.

3. Alves, A., Correia, A., Luque, J., and Phillips, A. J. L. 2004. Botryosphaeria corticola, sp. nov. on Quercus species, with notes and description of Botryosphaeria stevensii and its anamorph, Diplodia mutila. Mycologia 96:598613.

4. Amponsah, N. T., Jones, E. E., Ridgway, H. J., and Jaspers, M. V. 2009. Rainwater dispersal of Botryosphaeria conidia from infected grapevines. N. Z. Plant Prot. 62:228-233

5. Brown, G. E., and Lee, H. S. 1993. Interactions of ethylene with citrus stem-end rot caused by Diplodia natalensis. Phytopathology 83:1204-1208.

6. Burgess, T. I., Mohali, S., Pegg, G., de Beer, W., and Wingfield, M. J. 2006. Three new Lasiodiplodia spp. from the tropics, recognized based on DNA 
sequence comparisons and morphology. Mycologia 98:423-435.

7. Carbone, I., and Kohn L. M. 1999. A method for designing primer sets for speciation studies in filamentous ascomycetes. Mycologia 91:553-556.

8. Chen, S., Fichtner, E., Morgan, D., and Michailides, T. 2013. First report of Lasiodiplodia citricola and Neoscytalidium dimidiatum causing death of graft union of English walnut in California. Plant Dis. 97:993.

9. Childs, J. F. L. 1978. Rio Grande gummosis of citrus trees. Part 1. A brief review of the history and occurrence of Rio Grande gummosis. Plant Dis. Rep. 62:390-394.

10. Cenis J. L. 1992. Rapid extraction of fungal DNA for PCR amplification. Nucleic Acids Res. 20:2380-2380.

11. Crous, P. W., Slippers, B., Wingfield, M. J., Rheeder, J., Marasas, W. F. O., Philips, A. J. L., Alves, A., Burgess, T., Barber, P., and Groenewald, J. Z. 2006. Phylogenetic lineages in the Botryosphaeriaceae. Stud. Mycol. 55:235-253.

12. Denman, S., Crous, P. W., Taylor, J. E., Kang, J.-C., Pascoe, I., and Wingfield, M. J. 2000. An overview of the taxonomic history of Botryosphaeria, and a re-evaluation of its anamorphs based on morphology and ITS rDNA phylogeny. Stud. Mycol. 45:129-140.

13. Eskalen, A., Faber, B., and Bianchi, M. 2013. Spore trapping and pathogenicity of fungi in the Botryosphaeriaceae and Diaporthaceae associated with avocado branch canker in California. Plant Dis. 97:329-332.

14. Euro-MedCitrusNet. 2007. Safe and high quality supply chains and networks for the citrus industry between Mediterranean partner countries and Europe. Sixth Framework Programme. Contract No. 43146 (Food Quality and Safety). Deliverable 9: National Citrus Sector Analysis Pest and Diseases Report, Agadir, Morocco.

15. Fawcett, H. S. 1936. Citrus Diseases and Their Control. McGraw-Hill Book Company, Inc. New York and London.

16. Fawcett, H. S., and Burger, O. F. 1911. A gum-inducing Diplodia of peach and orange. Mycologia 3:151-153.

17. Feder, W. A., and Hutchins, P. C. 1966. Twig gumming and dieback of the 'Robinson' tangerine. Plant Dis. Rep. 50:429-430.

18. Grasso, S. 1983. Fungi associated with citrus gummosis cankers in Sicily. Inf. Fitopatol. 33:43-46.

19. Inderbitzin, P., Bostock, R. M., Trouillas, F. P., and Michailides, T. J. 2010. A six locus phylogeny reveals high species diversity in Botryosphaeriaceae from California almond. Mycologia 102:1350-1368.

20. Klotz, L. J. 1978. Fungal, bacterial and non-parasitic diseases and injuries originating in the seedbed, nursery, and orchard. Pages 1-66 in: The Citrus Industry, Vol. 4. W. Reuther, E. C. Calavan, and G. E. Carman, eds. University of California Press, Berkeley.

21. Jetter, K. M., Civerolo, E. L., and Sumner, D. 2003. Ex-ante economics of exotic disease policy: citrus canker in California. In: Exotic Pests and Diseases: Biology and Economics for Biosecurity. D. A. Sumner, ed. Iowa State Press, Ames.

22. Leavitt G. M. 1990. The occurrence, distribution, effect and control of Botryodiplodia theobromae on Vitis vinifera in California, Arizona and northern Mexico. Ph.D. dissertation, University of California, Riverside.

23. Loest, F. C. 1950. Orchard practices in relation to "collar rot" of citrus. Farming South Africa 25:331-333, 340

24. McDonald, V., and Eskalen, A. 2011. Botryosphaeriaceae species associated with avocado branch cankers in California. Plant Dis. 95:1465-1473.

25. Menge, J. A., and Ploetz, R. C. 2003. Diseases of avocado. Pages 35-71 in: Diseases of Tropical Fruit Crops. R. C. Ploetz, ed. CABI Publishing, Wallingford, UK.

26. Michailides, T. J. 1991. Pathogenicity, distribution, sources of inoculum, and infection courts of Botryosphaeria dothidea on pistachio. Phytopathology 81:566-573.

27. Phillips, A. J. L. 2002. Botryosphaeria species associated with diseases of grapevines in Portugal. Phytopathol. Mediterr. 41:3-18.

28. Phillips, A. J. L., Alves, A., Pennycook, S. R., Johnston, P. R., Ramaley, A., Akulov, A., and Crous, P. W. 2008. Resolving the phylogenetic and taxonomic status of dark-spored teleomorph genera in the Botryosphaeriaceae. Persoonia 21:29-55.

29. Phillips, A. J. L., Crous, P. W., and Alves, A. 2007. Diplodia seriata, the anamorph of "Botryosphaeria" obtusa. Fungal Divers. 25:141-155.

30. Punithalingam, E. 1980. Plant diseases attributed to Botryodiplodia theobromae. Pages 21-26 in: Biblioteca Mycologica. J. Cramer, Berlin.

31. Reuther, W., Calavan, E. C., and Carman, G. E., eds. 1978. The Citrus Industry, Vol. 4. University of California Press, Berkeley.

32. Rolshausen, P. E., Urbez-Torres, J. R., Rooney-Latham, S., Eskalen, A., Smith, R .J., and Gubler, W. D. 2010. Evaluation of pruning wound sus- ceptibility and protection against fungi associated with grapevine trunk diseases. Am. J. Enol. Vitic.61:113-119.

33. Salerno, M. 1957. Un parassita fogliare de Eucalyptus spp. (Cercospora eucalypti Cooke \& Massee) nuovo per I'Italia. Estratto da L'Italia Forestale e Montana 12:112-114.

34. Slippers, B., Crous, P. W., Denman, S., Coutinho, T. A., Wingfield, B. D. and Wingfield, M. J. 2004. Combined multiple gene genealogies and phenotypic characters differentiate several species previously identified as Botryosphaeria dothidea. Mycologia 96:83-101.

35. Slippers, B., Fourie, G., Crous, P. W., Coutinho, T. A., Wingfield, B. D., and Wingfield, M. J. 2004. Multiple gene sequences delimit Botryosphaeria australis sp. nov. from B. lutea. Mycologia 96:1030-1041.

36. Slippers, B., Johnson, G. I., Crous, P. W., Coutinho, T. A., Wingfield, B. D., and Wingfield, M. J. 2005. Phylogenetic and morphological re-evaluation of the Botryosphaeria species causing diseases of Mangifera indica. Mycologia 97:99-110.

37. Smith, C. O. 1934. Inoculations showing the wide host range of Botryosphaeria ribis. J. Agric. Res. 49:467-476.

38. Thompson, J. D., Gibson, T. J., Plewniak, F., Jeanmougin, F., and Higgins, D. G. 1997. The CLUSTAL X windows interface: flexible strategies for multiple sequence alignment aided by quality analysis tools. Nucleic Acids Res. 25:4876-4882.

39. Trouillas, F. P., Urbez-Torres, J. R., Peduto, F, and Gubler, W. D. 2010. First report of twig and branch dieback of English walnut (Juglans regia) caused by Neofusicoccum mediterraneaum in California. Plant Dis 94 1267.

40. Twizeyimana, M., McDonald, V., Mayorquin, J. S., Wang, D. H., Na, F., Akgül, D. S., and Eskalen, A. 2013. Effect of fungicide application on the management of avocado branch canker (formerly Dothiorella canker) in California. Plant Dis. 97:897-902.

41. Twizeyimana, M., Förster, H., McDonald, V., Wang, D. H., Adaskaveg, J. E., and Eskalen, A. 2013. Identification and pathogenicity of fungal pathogens associated with stem-end rot of avocado in California. Plant Dis. 97:1580-1584.

42. United States Department of Agriculture (USDA), National Agricultural Statistics Service. 2007. Census of Agriculture California State and County Data.

43. United States Department of Agriculture (USDA), National Agricultural Statistics Service (NASS). 2013. Citrus Fruits. Summary (September 2013). http://www.nass.usda.gov/Publications/Todays_Reports/reports/cfrt0913.pdf

44. Úrbez-Torres, J. R. 2011. The status of Botryosphaeriaceae species infecting grapevines. Phytopathol. Mediterr. 50(Suppl.):S5-S45.

45. Úrbez-Torres, J. R., Battany, M., Bettiga, L. J., Gispert, C., McGourty, G., Roncoroni, J., Smith, R. J., Verdegaal, P., and Gubler, W. D. 2010. Botryosphaeriaceae species spore-trapping studies in California vineyards. Plant Dis. $9: 717-724$

46. Úrbez-Torres, J. R., and Gubler, W. D. 2009. Pathogenicity of Botryosphaeriaceae spp. isolated from grapevine cankers in California. Plant Dis. 93:584-592.

47. Úrbez-Torres, J. R., and Gubler, W. D. 2011. Susceptibility of grapevine pruning wounds to infection by Lasiodiplodia theobromae and Neofusicoccum parvum. Plant Pathol. 6:261-270.

48. Úrbez-Torres, J. R., Leavitt, G. M., Guerrero, J. C., Guevara, J., and Gubler, W. D. 2008. Identification and pathogenicity of Lasiodiplodia theobromae and Diplodia seriata, the causal agents of bot canker disease of grapevines in Mexico. Plant Dis. 92:519-529.

49. Úrbez-Torres, J. R., Leavitt, G. M., Voegel, T. M., and Gubler, W. D. 2006. Identification and distribution of Botryosphaeria spp. associated with grapevine cankers in California. Plant Dis. 90:1490-1503.

50. Úrbez-Torres, J. R., Peduto, F., and Gubler, W. D. 2010. First report of grapevine cankers caused by Lasiodiplodia crassipora and Neofusicoccum mediterraneum in California. Plant. Dis. 94:785.

51. Úrbez-Torres, J. R., Peduto, F., Krueger, W. H., and Gubler, W. D. 2013 Olive twig and branch dieback: etiology, incidence, and distribution in California. Plant. Dis. 97:231-244.

52. White, T. J., Bruns, T., Lee, S., and Taylor, J. 1990. Pages 315-322 in: PCR Protocols: A Guide to Methods and Applications. Academic Press, San Diego, CA.

53. Wright, A. F., and Harmon, P. F. 2010. Identification of species in the Botryosphaeriaceae family causing stem blight on southern highbush blueberry in Florida. Plant Dis. 94:966-971.

54. Zentmyer, G. A. 1951. Avocado diseases. California Avocado Society, Yearbook. 36:97-101 